\title{
Hubungan Materi Pembelajaran Pendidikan Agama Islam dengan Kecerdasan Emosional Siswa
}

\author{
M. YUSUF AHMAD* \\ SITI NURJANAH** \\ *Fakultas Agama Islam (FAI) Universitas Islam Riau (UIR) \\ Jl. Kaharuddin Nasution No.113 Perhentian Marpoyan Pekanbaru 28284 \\ Hp: 081365542760 \\ **Fakultas Agama Islam (FAI) Universitas Islam Riau (UIR) \\ Jl. Kaharuddin Nasution No.113 Perhentian Marpoyan Pekanbaru 28284
}

\begin{abstract}
Abstrak: Kecerdasan emosional merupakan salah satu kecerdasan yang dimiliki oleh setiap individu dan merupakan salah satu kecerdasan yang dianggap penting. Dengan memiliki kecerdasan emosional, seseorang mampu memotivasi diri sendiri dan bertahan menghadapi frustasi, mengendalikan dorongan hati dan tidak melebih-lebihkan kesenangan, mengatur suasana hati dan menjaga agar beban stres tidak melumpuhkan kemampuan berfikir, berempati dan berdoa. Selain itu, seseorang yang memiliki kecerdasan emosional juga akan mampu menjalani hidup hanya berorientasi pada kebutuhan, bukan keinginan. Pencerdasan emosional dilakukan menurut pencerdasan intelegensi dan pencerdasan spiritual. Pencerdasan spiritual dapat diperoleh melalui pendidikan Agama Islam. Selain itu, dalam materi pembelajaran pendidikan Agama Islam juga mengandung ajaran tentang kecerdasan emosional. Oleh karena itu, melalui penelitian ini, penulis meneliti hubungan materi pembelajaran pendidikan Agama Islam dengan kecerdasan emosional siswa kelas VII SMP PGRI Pekanbaru. Berdasarkan hasil pengolahan dan analisis data yang telah penulis lakukan, maka diperoleh kesimpulan bahwa terdapat hubungan yang signifikan antara materi pembelajaran pendidikan Agama Islam dengan kecerdasan emosional siswa kelas VII SMP PGRI Pekanbaru.
\end{abstract}

Kata kunci : materi pembelajaran PAI, kecerdasan emosional.

\section{PENDAHULUAN}

Manusia merupakan makhluk ciptaan Allah SWT yang paling sempurna. Dalam diri manusia terdapat berbagai potensi yang harus dikembangkan. Pengembangan potensi tersebut dapat dilakukan melalui bimbingan, sehingga setiap potensi yang dimiliki oleh seorang manusia akan berkembang.
Bimbingan dapat diperoleh melalui pendidikan. Pendidikan merupakan salah satu kebutuhan manusia yang senantiasa memiliki rasa ingin tahu. Dan melalui pendidikan pula manusia akan memperoleh sesuatu yang ingin diketahuinya. Selanjutnya, Marimba (1989: 19) berpendapat bahwa Pendidikan adalah bimbingan atau pimpinan secara sadar oleh si pendidik 
terhadap perkembangan jasmani dan rohani si terdidik menuju terbentuknya kepribadian yang utama. Maka, untuk membentuk kepribadian yang utama, dibutuhkan peranan pendidikan termasuk peranan pendidikan agama. Pendidikan agama Islam dipercaya dapat menjadi salah satu alternatif untuk membentuk pribadi yang utama.

Pendidikan Islam diyakini mampu menciptakan kepribadian utama yang di dalamnya terdapat aqidah yang kuat mengakar sehingga iman yang ada dalam dirinya kokoh, melaksanakan ibadah secara kontinu dan istiqomah sehingga dapat beramal secara ikhlas, dan berakhlakul karimah sebagai aplikasi dari iman dan amal sehingga dapat mencapai derajat ihsan.

Nata (2003: 86) mengungkapkan bahwa Al-Ghazali menyatakan bahwa pendidikan memiliki 2 tujuan, yaitu: (1) Tercapainya kesempurnaan insan yang bermuara pada pendekatan diri kepada Allah SWT; dan (2) Kesempurnaan insan yang bermuara pada kebahagian dunia dan akhirat. Dengan kata lain pendidikan juga bertujuan untuk mencapai kebahagiaan dunia dan akhirat. Jika seseorang ingin memperoleh kebahagiaan di dunia, ia harus memiliki ilmu untuk dapat mencapai kebahagiaan tersebut. Sebaliknya, jika seseorang ingin memperoleh kebahagiaan di akhirat, ia harus memiliki ilmu untuk dapat mencapai kebahagiaan tersebut. Dan jika seseorang ingin memperoleh kebahagiaan di dunia dan akhirat, ia juga harus memiliki ilmu tentang kedua hal tersebut.

Selanjutnya, pendidikan Islam juga mampu menciptakan generasi muslim yang beriman dan bertaqwa kepada Allah SWT, berakhlak, berpengetahuan, terampil, dan mampu menyelesaikan setiap persoalan yang ada. Menurut Choeroni (2013), dalam pendidikan Islam terdapat beberapa materi, yaitu:
(1) Membaca Al-Quran dengan Tartil; (2) Iman Kepada Allah SWT; (3) Iman Kepada Malaikat; (4) Taharah; (5) Shalat Wajib Berjamaah; (6) Shalat Jum'at; (7) Shalat Jamak dan Qasar; (8) Kewajiban Menuntut Ilmu; (9) Sikap Ikhlas, Sabar, dan Pemaaf; (10) Perjuangan Nabi Muhammad SAW; dan Khulafaurrasyidin.

Materi pendidikan islam tersebut bertujuan pada satu titik, yaitu menciptakan manusia yang berakhlakul karimah. Perbaikan akhlak merupakan tantangan sejak zaman Rasulullah SAW. Maka, pada zaman sekarang ini membentuk dan memperbaiki akhlak generasi muslim merupakan tantangan bagi para pendidik pendidikan Islam.

Materi-materi yang ada dalam pendidikan Islam tidak hanya untuk dipelajari dan dipahami, tetapi juga untuk diamalkan. Dengan mengaplikasikan seluruh teori yang telah diperoleh, setidaknya seseorang mampu mendengarkan suara hati nuraninya, karena hati nurani tidak akan bertentangan dengan ajaran Islam, dan materi yang ada dalam pendidikan Islam bermuara pada hati nurani. Dengan mendengarkan setiap kata hati nurani, seseorang akan mampu meyelesaikan setiap persoalan sesuai dengan kata hati nuraninya.

Agama Islam tidak hanya mengatur hubungan antara manusia dengan Tuhan saja, tetapi juga mengatur hubungan antara manusia dengan manusia, dan mengatur hubungan antara manusia dengan alam. Dalam pendidikan Islam akan ditemukan materi yang membahas tentang hal tersebut. Dalam hubungan antar manusia, dibutuhkan kejernihan hati nurani dalam berperilaku dan bertindak agar manusia bisa saling mengerti dan memahami yang akhirnya akan tercipta suasana yang harmonis serta setiap persoalan akan mampu diselesaikan. 
Seseorang yang memiliki kemampuan tersebut berarti telah memiliki kecerdasan emosional. Kecerdasan emosional merupakan kemampuan seseorang dalam mengenali emosi diri sendiri dan orang lain, mengelola suasana hati, memotivasi diri, dan mengembangkan hubungan dengan orang lain.

Menurut Suhartono (2008: 140), Pencerdasan emosional dilakukan menurut pencerdasan intelegensi dan pencerdasan spiritual. Pencerdasan spiritual dapat diperoleh melalui pendidikan Agama Islam, sehingga siswa dapat memperoleh kecerdasan emosional melalui pembelajaran pendidikan Agama Islam.

Berdasarkan studi pendahuluan yang penulis lakukan, banyak siswa di SMP PGRI Pekanbaru kurang memiliki akhlak mulia yang berhubungan dengan kecerdasan emosional, dan hal ini terlihat dari fenomena yang penulis lihat di SMP PGRI pekanbaru sebagai berikut: (1) Kurang bertanggung jawab terhadap tugas yang diberikan. Setiap melakukan proses pembelajaran, tentu akan ada tugas yang diberikan, baik tugas yang harus diselesaikan di kelas secara kelompok, ataupun tugas yang harus diselesaikan di rumah. Ketika mendapatkan tugas kelompok di kelas, sebagian kelompok hanya bergantung pada satu atau dua orang teman kelompoknya tanpa mau bekerja sama untuk menyelesaikan tugas yang diberikan. Sementara kelompok yang lain hanya asik bercerita tanpa mau menyelesaikan tugas yang diberikan; (2) Kurang optimis. Optimis berarti tidak mudah menyerah, selalu beranggapan bahwa apa yang dilakukan akan berhasil, dan terus berusaha dengan keyakinan bahwa apa yang diinginkan pasti tercapai. Ketika ditugaskan untuk mencari berbagai ayat dan hadits yang berkaitan dengan materi yang diajarkan, kebanyakan siswa langsung pesimis dan mengatakan bahwa mereka tidak bisa menemukan ayat ataupun hadist yang berkaitan dengan materi dan hanya dalam waktu beberapa menit mereka sudah menyerah; (3) Kurang mau mendengarkan dengan baik. Pada saat proses pembelajaran berlangsung, sebagian siswa tidak mau mendengarkan penjelasan materi yang diberikan oleh guru, ada sebagian siswa yang bercerita dengan temannya. Jika proses pembelajaran dilakukan dengan baik, seharusnya siswa bisa mendengarkan dengan baik, tetapi pada kenyataannya kebanyakan siswa tidak melakukan hal tersebut.

Adapun rumusan masalah pada penelitian ini: apakah ada hubungan materi pembelajaran Pendidikan Agama Islam dengan Kecerdasan Emosional Siswa kelas VII SMP PGRI Pekanbaru. Sedangkan tujuan penelitian ini adalah untuk mengetahui ada atau tidaknya hubungan yang signifikan antara materi pembelajaran pendidikan Agama Islam dengan kecerdasan emosional Siswa kelas VII SMP PGRI pekanbaru. Selanjutnya, Penelitian ini juga diharapkan dapat berguna untuk: (1) Guru PAI, sebagai pertimbangan untuk menyeimbangkan Intelegence Quotient (IQ) dengan Emotional Quotient (EQ) dalam pembelajaran; (2) Sekolah, khususnya bagi kepala sekolah agar mengingatkan kepada para pendidik bahwa Intelegence Quotient (IQ) saja tidak cukup, tetapi harus dilengkapi dengan Emotional Quontient (EQ); dan (3) Departemen Agama dan Departemen Pendidikan Nasional, sebagai bahan evaluasi untuk memperhatikan Emotional Quontient (EQ).

\section{KONSEP TEORI}

\section{Hakikat Pendidikan Agama Islam (PAI)}

Pendidikan Agama Islam berkenaan dengan tanggung jawab 
bersama. Oleh sebab itu usaha yang secara sadar dilakukan oleh guru mempengaruhi siswa dalam rangka pembentukan manusia beragama yang diperlukan dalam pengembangan kehidupan beragama dan sebagai salah satu sarana pendidikan nasional dalam rangka meningkatkan ketaqwaan terhadap Tuhan Yang Maha Esa.

Menurut Daradjat (1996: 86), pendidikan agama Islam atau AtTarbiyah Al-Islamiah adalah usaha bimbingan dan asuhan terhadap anak didik agar kelak setelah selesai pendidikannya dapat memahami dan mengamalkan ajaran Agama Islam serta menjadikannya sebagai pandangan hidup.

Sedangkan menurut Ahmad D. Marimba dalam Uhbiyati, pendidikan Islam adalah: bimbingan jasmani dan rohani berdasarkan hukumhukumAgama Islam, menuju terciptanya kepribadian utama menurut ukuran Islam (Uhbiyati: 1998: 9).

Dari beberapa definisi di atas, maka dapat diambil pengertian bahwa yang dimaksud Pendidikan Agama Islam adalah suatu aktivitas atau usaha-usaha tindakan dan bimbingan yang dilakukan secara sadar dan sengaja serta terencana yang mengarah pada terbentuknya kepribadian anak didik yang sesuai dengan norma-norma yang ditentukan oleh ajaran Agama.

Pendidikan Agama Islam juga merupakan upaya sadar dan terencana dalam menyiapkan peserta didik untuk mengenal, memahami, menghayati, hingga mengimani, bertaqwa, dan berakhlak mulia dalam mengamalkan ajaran Agama Islam dari sumber utamanya yaitu kitab suci Al-Quran dan Al-Hadits, melalui kegiatan bimbingan pengajaran, latihan, serta penggunaan pengalaman.

Dari pengertian di atas terbentuknya kepribadian yakni pendidikan yang diarahkan pada terbentuknya kepribadian Muslim. kepribadian Muslim adalah pribadi yang ajaran Islamnya menjadi sebuah pandangan hidup, sehingga cara berpikir, merasa, dan bersikap sesuai dengan ajaran Islam.

Dengan demikian Pendidikan Agama Islam itu adalah usaha berupa bimbingan, baik jasmani maupun rohani kepada anak didik menurut ajaran Islam, agar kelak dapat berguna menjadi pedoman hidupnya untuk mencapai kebahagiaan hidup dunia dan akhirat.

\section{Materi Pembelajaran PAI}

Materi atau bahan pelajaran atau yang dikenal dengan materi pokok merupakan subtansi yang akan diajarkan dalam kegiatan belajar mengajar. Materi pokok adalah materi pelajaran bidang studi dipegang atau diajarkan oleh guru. Keberhasilan pembelajaran secara keseluruhan sangat tergantung padakeberhasilan guru merancang materi pembelajaran. Materi Pembelajaran padaha kekatnya merupakan bagian tak terpisahkan dari Silabus, yakni perencanaan, prediksi dan proyeksi tentang apa yang akan dilakukan pada saat Kegiatan Pembelajaran. Secara garis besar dapat dikemukakan bahwa Materi pembelajaran (instructional materials) adalah pengetahuan, keterampilan, dan sikap yangharus dikuasai peserta didik dalam rangka memenuhi standar kompetensi yangditetapkan. Materi pembelajaran menempati posisi yang sangat penting darikeseluruhan kurikulum, yang harus dipersiapkan agar pelaksanaan pembelajaran dapat mencapai sasaran. Sasaran tersebut harus sesuai dengan Standar Kompetensi dan Kompetensi Dasar yang harus dicapai oleh pesertadidik. Artinya, materi yang ditentukan untuk kegiatan pembelajaran hendaknya materi yang benar-benar menunjang tercapainya 
standar kompetensi dan kompetensi dasar, serta tercapainya indikator.

Agama berarti risalah yang disampaikan Tuhan kepada Nabi sebagai petunjuk bagi manusia dan hukumhukum sempurna untuk dipergunakan manusia dalam penyelenggaraan tata cara hidup yang nyata serta mengatur hubungan dengan tanggung jawab kepada Allah dan masyarakat sekitarnya. Dan pendidikan Agama Islam dapat diartikan sebagai program yang terencana dalam menyiapkan peserta didik untuk mengenal, memahami, menghayati hingga mengimani ajaran Islam serta diikuti tuntunan untuk menghormati Agama lain dalam hubungan dengan kerukunan antara umat beragama hingga terwujud kesatuan dan persatuan bangsa.

Setelah melihat kedua pengertian diatas maka dapat disimpulkan bahwa materi PAI adalah materi pelajaran atau materi pokok bidang studi Islam yang lakukan secara terencana guna menyiapkan peserta didik untuk mengenal, memahami, menghayati, mengimani, mengamalkan ajaran Islam dan berakhlak secara Islam serta diikuti tuntunan untuk menghormati Agama lain dalam hubungan dengan kerukunan antara umat beragama hingga terwujud kesatuan dan persatuan bangsa.

\section{Jenis-Jenis Materi PAI}

Adapun materi pembelajaran Pendidikan Agama Islam kelas VII sesuai dengan kurikulum 2013 (Choeroni, et.al., 2013) adalah dengan kompetensi dasar pembelajaran meliputi: (1)Membaca Al-Qur'an dengan Tartil dengan submateri pembelajaran yaitu: Membaca Al-Qur'an dengan tartil; (b) Menghafal ayat dari beberapa surat; (c) Hukum bacaan mad; (d) Pengertian bacaan mad; dan (e) Macam-macam bacaan mad; (2) Beriman kepada Allah SWT, dengan sub materi pembelajaran yaitu: (a) Pengertian Iman kepada Allah; (b) Sifat wajib bagi Allah; (c) Tanda-tanda adanya Allah SWT; dan (d) Berperilaku yang mencerminkan ketaatan kepada Allah SWT; (3) Beriman kepada malaikat Allah SWT, dengan sub materi pembelajaran yaitu: (a) Pengertian iman kepada malaikat Allah SWT; (b) Tugas-tugas malaikat Allah; (c) Sifat malaikat dan perbedaannya dengan makhluk gaib lain; dan (d) Hikmah dan perilaku beriman kepada malaikat Allah SWT; (4) Menerapkan ketentuan bersuci dari hadats kecil dan hadats besar berdasarkan syariat Islam, dengan sub materi pembelajaran yaitu: (a) Pengertian taharah; (b) Hadas dan cara mensucikannya; (c) Najis dan cara menyucikannya; (d) Perbedaan hadas dan najis; (e) Wudu; (f) Tayamum; (g) Mandi wajib; (h) Praktik wudu; (i) Praktik tayamum; dan (j) Praktik mandi wajib; (5) Menunaikan shalat wajib berjamaah sebagai implementasi dari pemahaman rukun islam, dengan sub materi pembelajaran yaitu: (a) Ketentuan dan tata cara shalat; (b) Pengertian shalat; (c) Hukum shalat lima waktu; (d) Syarat wajib shalat; (e) Syarat sah shalat; (f) Rukun shalat; (g) Sunah shalat; (h) Hal-hal yang membatalkan shalat; (i) Ketentuan waktu shalat wajib; (j) Praktik shalat wajib; (k) Pentingnya shalat wajib dalam kehidupan; (l) Shalat wajib pada awal waktu; (m) Shalat fardu berjamaah; (n) Hukum shalat berjemaah; (o) Pengaturan saf (barisan shalat); (p) Ketentuan iman dan makmum; (q) Keutamaan shalat berjemaah; dan (r) Praktik shalat wajib berjamaah; (6) Menunaikan shalat jum'at sebagai implementasi dari pemahaman Q.S AlJum'ah (62): 9 dengan sub materi pembelajaran yaitu: (a) Melaksanakan shalat Jum'at; (b) Ketentuan shalat Jum'at; dan (c) Praktik shalat Jum'at; (7) Menunaikan shalat jamak dan qasar ketika bepergian jauh (musafir) sebagai 
implementasi dari pemahaman ketaatan beribadah, dengan sub materi pembelajaran yaitu: (a) Shalat jamak; (b) Shalat qasar; (c) Shalat jamak qasar; dan (d) Praktik shalat jamak, qasar, dan jamak qasar; (8) Menghargai perilaku semangat menuntut ilmu sebagai implementasi dari pemahaman sifat Allah (Al-'Alim, Al-Khabir, As-Sami', dan Q.S Al-Mujadalah (58): 11 dan Q.S ArRahman (55):33 serta hadits terkait; (9) Menghargai perilaku ikhlas, sabar, dan pemaaf sebagai implementasi dari pemahaman Q.S. An-Nisa (4): 146, Q.S. Al-Baqarah (2): 153, dan Q.S. Ali Imran (3): 134, dan hadits terkait; (10) Memahami sejarah perjuangan Nabi Muhammad SAW; (11) Mengetahui karakter Khalifah dari Khulafaurrasyidin, dengan sub materi pembelajaran yaitu: (a) Pengertian Khulafaurrasyidin; (b) Kahlifah Abu Bakar As Sidiq r.a (1113 H/632-643 M); (c) Khalifau Umar bin Khattab r.a (13-23 H/634-644 M); (d) Khalifah Usman bin Affan r.a (23-36 H/644-656 M); dan (e) Khalifah Ali bin Abi Thalib r.a (36-41 H/656-661 M).

\section{Hakikat Kecerdasan Emosional}

Istilah kecerdasan emosi diperkenalkan pada tahun 1990 oleh dua ahli psikologi yaitu Peter Salovey dan John Mayer. Emotional intellegence (EI) mengacu pada kemampuan memahami dan menangani perasaan diri seseorang dan orang lain. Daniel Goleman mengembangkan konsep Emotional intellegence (EI) tersebut dengan memasukkan ciri-ciri seperti optimis, kesadaran, motivasi, empati, dan kompetensi sosial (Nuryati, 2008: 43). Sebagai pencetus pertama istilah kecerdasan emosional, Peter Salovey dan John Mayer mengemukakan bahwa kecerdasan emosional adalah kemampuan untuk mengenali perasaan, meraih dan membangkitkan perasaan untuk membantu pikiran, memahami perasaan dan maknanya, serta mengendalikan perasaan secara mendalam sehingga membantu perkembangan emosi dan itelektual (Uno, 2010: 69). Menurut Daniel Goleman kecerdasan emosional adalah kemampuan untuk memotivasi diri sendiri dan bertahan menghadapi frustasi, mengendalikan dorongan hati dan tidak melebih-lebihkan kesenangan, mengatur suasana hati dan menjaga agar beban stres tidak melumpuhkan kemampuan berpikir, berempati dan berdoa (Uno, 2010: 68).

Sementara itu, Agustian (2007: 280) berpendapat bahwa kecerdasan emosional adalah kemampuan merasakan, memahami secara efektif, menerapkan daya dan kepekaan emosi sebagai sumber energi, informasi koneksi, dan pengaruh. Dalam Islam, hal-hal yang berhubungan dengan kecakapan emosional adalah konsistensi (istiqamah), kerendahan hati (tawadhu), berusaha dan berserah diri (tawakkal), ketulusan (keikhlasan), totalitas (kaffah), keseimbangan (tawazun), integritas dan penyempurnaan (ihsan).

Jadi, kecerdasan emosional adalah kemapuan seseorang dalam mengenali emosi diri sendiri dan orang lain, mampu memotivasi diri dan merasakan apa yang dirasakan orang lain, serta mampu manjalin hubungan sosial yang baik dengan orang lain sehingga setiap permasalahan yang timbul dapat diselesaikan dengan baik. Jika seseorang telah memiliki kecerdasan emosional, maka ia akan mampu mengendalikan emosinya.

Kecerdasan emosionallah yang memotivasi seseorang untuk mencari manfaat dan mengaktifkan aspirasi dan nilai-nilai yang paling dalam, mengubah apa yang dijalani. Kecerdasan emosional menuntut seseorang belajar mengakui dan menghargai perasaan dirinnya dan orang lain untuk ditanggapi dengan tepat, menerapkan dengan efektif 
informasi dan energi emosi dalam kehidupan dan pekerjaan sehari-hari (Uno, 2010: 71).

Dengan demikian, kecerdasan emosional merujuk pada kemampuan mengenali perasaan sendiri dan orang lain, kemampuan memotivasi diri sendiri, dan kemampuan mengelola emosi dengan baik pada diri sendiri maupun dalam hubungannya dengan orang lain (Goleman \& Uno, 2010: 72).

Komponen kecerdasan emosional menurut Daniel Goleman adalah: (1) Mengenali emosi diri sendiri, terdiri dari: (a) Kesadaran diri, (b) Penilaian diri secara teliti; dan (c) Percaya diri; (2) Mengelola suasana hati, terdiri dari: (a) Mengendalikan diri, (b) Dapat dipercaya; (c) Kewaspadaan; (d)Adaptabilitas; dan (e) Inovasi; (3) Memotivasi diri sendiri, terdiri dari: (a)Dorongan berprestasi, (b) Komitmen, (c)Inisiatif; dan (d) Optimisme; (4) Mengenali emosi orang lain, terdiri dari: (a) Memahami orang lain; (b)Berorientasi pelayanan; (c) Mengembangkan orang lain; (d) Mengatasi keragaman; dan (e) Kesadaran politis; dan (5) Mengembangkan hubungan dengan orang lain, terdiri dari: (a) Pengaruh; (b) Komunikasi; (c) Kepemimpinan; (d) Katalisator perubahan; (e) Manajemen konflik; (f) Pengikat jaringan; (g) Kolaborasi dan koorperasi; dan (g) Kemampuan tim.

\section{Hubungan Materi Pembelajaran Pendidikan Agama Islam Dengan Kecerdasan Emosional}

Pembelajaran Pendidikan Agama

Islam adalah suatu upaya yang dilakukan oleh pendidik pendidikan Agama Islam untuk membelajarkan peserta didik agar dapat mencapai tujuan yang diinginkan, yaitu menjadi manusia paripurna atau insan kamil yang terefleksi dalam kehidupan seharihari. Dalam kegiatan pembelajaran, sebaiknya pendidik tidak hanya memperhatikan kecerdasan emosional yang tidak kalah penting dalam kehidupan.

Kecerdasan emosional mencakup kemampuan yang berbeda tetapi saling melengkapi dengan kecerdasan akademik, yaitu kemampuan kognitif murni yang dilakukan IQ (Ramayulis, 2011: 93). Kecerdasan emosi juga bekerja secara dengan keterampilan kognitif (Uno, 2010: 69). Oleh karena itu, dengan adanya materi pembelajaran pendidikan agama Islam diharapkan terlahir generasi muslim yang tidak hanya cerdas secara intelektual tetapi juga cerdas secara emosional sehingga mampu menyelesaikan setiap permasalahan yang ada dengan bijaksana.

Setiap materi pembelajaran yang direalisasikan memiliki tujuan untuk merubah tingkah laku peserta didik dari yang tidak baik menjadi baik sehingga materi yang telah disampaikan benarbenar memberikan pegaruh bagi para peserta didik. Begitu juga pendidikan agama Islam, materi pembelajaran yang dilaksanakan diharapkan mampu berpengaruh bagi para peserta didik. Jika dalam kecerdasan emosional terdapat komponen mengenali emosi sendiri, dan mengelola suasana hati, memotivasi diri sendiri, mengenali emosi orang lain, dan mengembangkan hubungan dengan orang lain. Maka, dalam Islam mengajarkan agar seseorang tetap percaya diri bagaimanapun kelemahan yang dimiliki, mampu mengendalikan diri saat cobaan dan ujian datang (istiqamah), tetap optimis dan berusaha walaupun banyak cobaan yang menghalangi untuk mencapai tujuan (tawakkal), menjalin komunikasi yang baik dengan orang lain agar dapat saling memahami, dan menjalin silaturahmi dengan sesama.

Jika materi pembelajaran Pendidikan Agama Islam direalisasikan 
dengan baik, maka peserta didik akan memperoleh hal-hal tersebut sehingga berpengaruh bagi mereka yang berimbas pada kecerdasan emosional mereka. Mereka tidak hanya akan memiliki kecerdasan intelektual yang baik, tetapi juga kecerdasan emosional yang baik. Menurut Mahmud al-Zaky kecerdasan emosional pada dasarnya memiliki hubungan yang erat dengan kecerdasan uluhiyah (ketuhanan) (Ramayulis, 2011: 93-94). Jika tingkat pemahaman dan pengamalan nilai-nilai ketuhanan seseorang tinggi dalam hidupnya, maka ia telah memiliki kecerdasan emosional yang tinggi pula. Hal ini berarti bahwa ketika peserta didik telah menerima dan mengamalkan setiap materi yang diterima dalam proses pembelajaran, maka mereka juga telah memiliki kecerdasan emosional. Hal ini juga menujukkan bahwa materi yang telah mereka terima berpengaruh bagi kecerdasan emosional mereka.

\section{METODE}

Penelitian ini merupakan penilitian korelasional karena penelitian ini bermaksud untuk mengetahui pengaruh antara dua variabel, yakni Materi Pembelajaran Pendidikan Agama Islam (X) sebagai variabel bebas dan Kecerdasan Emosional (Y) sebagai variabel terkaitnya.

Model korelasional bertujuan untuk mendeteksi seberapa jauh variabel-variabel pada suatu faktor terkait dengan variabel-variabel pada faktor lain berdasarkan koefisian korelasi. Koefisien korelasi ini akan menerangkan sejauh mana variabel tersebut berkorelasi sedangkan dalam pengujian hipotesis, koefisien akan menunjukkan tingkat signifikan teruji tidaknya hipotesis.

Penelitian ini dilaksanakan di SMP PGRI Pekanbaru mulai bulan Februari 2015 sampai Mei 2015 dengan subjek dalam penelitian ini adalah siswa kelas VII SMP PGRI Pekanbaru. sedangkan objek penelitian ini adalah hubungan materi pembelajaran pendidikan Agama Islam dengan kecerdasan emosional.

Adapun yang menjadi populasi dalam penelitian ini adalah siswa kelas VII SMP PGRI Pekanbaru yang berjumlah 150 orang. Karena jumlahnya lebih dari 100 orang, maka tidak seluruh populasi yang penulis teliti. Sedangkan jumlah sampel adalah 25\% dari 150 orang yaitu 37 orang. Teknik sampel yang digunakan pada penelitian ini adalah random sampling.

Adapun metode pengumpulan data yang digunakan adalah Angket (Kuesioner) dan Dokumentasi. Angket adalah kumpulan pertanyaan yang diajukan secara tertulis kepada seseorang (responden), dan cara menjawabnya juga dilakukan dengan tertulis. Sedangkan dokumentasi adalah metode yang digunakan untuk memperoleh data-data yang terdapat dalam dokumen-dokumen data yang diambil dari data tertulis seperti buku induk, raport, dokumen, catatan harian, surat keterangan dan sebagainya.

Penelitian ini adalah penelitian deskriptif menggunakan pendekatan korelasional, angket diberikan kepada siswa yang merupakan sampel yaitu yang terdiri dari 5 kelas yang diambil berdasarkan populasi yang homogeny. Setiap kelas diambil 25\% dari populasi maka jumlah sampelnya adalah sebanyak 37 orang siswa dari 150 orang siswa yang menjadi populasi. Setiap kelas tersebut dilakukan sampling acak yaitu dengan cara pengundian, sehingga ditemukan 7-8 responden disetiap kelasnya yaitu secara keseluruhan adalah sebanyak 37 responden.

Analisis statistik yang dipakai adalah statistik presentase. Untuk menganalisa data yang telah diperoleh maka peneliti mengubah data tersebut dalam bentuk persentase, dengan 
menggunakan rumus presentase sebagai berikut:

2011:43)

$$
p=\frac{f}{N} \times 100 \% \quad \text { (Sudijono, }
$$

keterangan:

$p=$ angka presentasi

$f=$ frekuensi skor jawaban siswa

$N=$ jumlah responden

Penelitian ini merupakan penelitian korelasi, yang bertujuan untuk menemukan ada tidaknya hubungan dan apabila ada seberapa besarnya hubungan serta berarti atau tidaknya hubungan tersebut. Dalam hal ini untuk menentukan hubungan materi pembelajaran pendidikan Agama Islam dengan kecerdasan emosional digunakan korelasi product moment, seperti rumus berikut:

$r_{x y}=\frac{n\left(\sum X Y\right)-\left(\sum X\right) \cdot\left(\sum Y\right)}{\sqrt{\left\{n \cdot \sum X^{2}-\left(\sum X\right)^{2}\right\} \cdot\left\{n \cdot \sum Y^{2}-\left(\sum Y\right)^{2}\right\}}}$

keterangan:

$X=$ materi pembelajaran pendidikan Agama Islam

$Y \quad=$ kecerdasan emosional

$\sum X=$ jumlah skor total $X$

$\sum Y=$ jumlah skor total $Y$

$n \quad=$ jumlah responden

Korelasi product moment dilambangkan dengan $(r)$, kriteria penafsiran mengenai indeks korelasinya $(r)$ dapat dilihat sebagai berikut:

(a) antara 0,80-1,00 : sangat kuat; (b) antara 0,60 - 0,799 : kuat; (c) antara 0,40 - 0,599 : cukup kuat; (d) antara 0,20 - 0,399 : rendah; dan (e) antara 0,00-0,199 : sangat rendah (Riduwan, 2010: 138).

Untuk mengetahui apakah ada hubungan materi pembelajaran pendidikan Agama Islam dengan kecerdasan emosional dari data sampel dapat menduga populasi perlu diketahui signifikanhubungan tersebut.Uji signifikan dilakukan dengan uji t. Pengujian ini bertujuan untuk mengetahui besarnya hubungan masingmasing variabel. Langkah-langkah yang digunakan dalam penyajian ini adalah (1) Menentukan Hipotesis. Dalam penelitian ini hipotesis yang digunakan adalah sebagai berikut: (a) $H_{O}=$ Tidak terdapat hubungan yang signifikan antara materi pembelajaran pendidikan agama islamdengan kecerdasan emosional; dan (b) $H_{a}=$ Terdapat hubungan yang signifikan antara materi pembelajaran pendidikan agama islamdengan kecerdasan emosional. (2) Menghitung nilai $t$ pada korelasi product moment menggunakan rumus:

$$
\begin{aligned}
& t_{\text {hitung }}=\frac{r \sqrt{n-2}}{\sqrt{1-r^{2}}} \\
& \text { dimana: } \\
& t_{\text {hitung }}=\text { Nilai } t_{\text {hitung }} \\
& n=\text { jumlah responden } \\
& r=\text { koefisien korelasi } \quad r_{\text {hitung }} \\
& \text { (Riduwan, 2010: 98) } \\
& \text { Untuk menguji kebenaran atau }
\end{aligned}
$$
kepalsuan dari hipotesis $H_{a}$ dan $H_{O}$ tersebut maka langkah selanjutnya adalah membandingkan besarnya $t_{\text {hitung }}$ dengan besarnya $t_{\text {tabel }}$ dengan terlebih dahulu mencari derajat bebas $(d b)$ atau degrees of freedom dengan rumus sebagai berikut:

$d f=N-n r$

keterangan:

$d f=$ degrees of freedom

$N=$ banyaknya variabel yang dikorelasikan

Dengan diperolehnya $d f$ maka dapat dicari besarnya $t_{\text {tabel }}$ yang pada taraf signifikan $5 \%$. Jika $t_{\text {hitung }}>t_{\text {tabel }}$ maka $H_{O}$ ditolak dan $H_{a}$ diterima artinya terdapat hubungan yang signifikan antara materi pembelajaran pendidikan agama islamdengan kecerdasan emosional.

\section{Konsep Operasional}

Sesuai dengan judul Hubungan Materi Pembelajaran Pendidikan Agama Islam dengan Kecerdasan Emosional siswa kelas VII SMP PGRI Pekanbaru, untuk lebih terarah maka disusun 
konsep operasional materi pembelajaran pendidikan Agama Islam sesuai dengan kurikulum 2013 adalah sebagai variabel X: (1) Membaca Al-Qur'an dengan Tartil, meliputi: (a) Siswa mampu membaca Al-Qur'an dengan tartil; (b) Siswa mampu menghafal ayat dari beberapa surat; dan (c) Siswa memahami hukum bacaan mad. (2) Beriman kepada Allah SWT, meliputi: (a) Siswa mengetahui pengertian Iman kepada Allah; (b) Siswa mengetahui Sifat wajib bagi Allah; (c) Siswa mengetahui tanda-tanda adanya Allah SWT; dan (d) Siswa mengetahui berperilaku yang mencerminkan ketaatan kepada Allah SWT. (3) Beriman kepada malaikat Allah SWT, meliputi: (a) Siswa mengetahui pengertian iman kepada malaikat Allah SWT; (b) Siswa mengetahui tugas-tugas malaikat Allah; (c) Siswa mengetahui sifat malaikat dan perbedaannya dengan makhluk gaib lain; dan (d) Siswa mengetahui hikmah dan perilaku beriman kepada malaikat Allah SWT. (4) Menerapkan ketentuan bersuci dari hadats kecil dan hadats besar berdasarkan syariat Islam, meliputi: (a) Siswa mengetahui pengertian taharah; (b) Siswa mengetahui hadas dan cara mensucikannya; (c) Siswa mengetahui najis dan cara menyucikannya; (d) Siswa mengetahui perbedaan hadas dan najis; (e) Siswa mengetahui cara berwudu; (f) Siswa mengetahui cara bertayamum; (g) Siswa mengetahui cara mandi wajib; dan (h) Siswa mengetahui manfaat taharah dalam kehidupan. (5) Menunaikan shalat wajib berjamaah sebagai implementasi dari pemahaman rukun islam, meliputi: (a) Siswa mengetahui ketentuan dan tata cara shalat; (b) Siswa mengetahui pengertian shalat; (c) Siswa mengetahui hukum shalat lima waktu; (d) Siswa mengetahui syarat wajib shalat; (e) Siswa mengetahui syarat sah shalat; (f) Siswa mengetahui rukun shalat; (g) Siswa mengetahui sunah shalat; (h) Siswa mengetahui hal-hal yang membatalkan shalat; (i) Siswa mengetahui ketentuan waktu shalat wajib; dan (j) Siswa mengetahui pentingnya shalat wajib dalam kehidupan. (6) Menunaikan shalat jum'at sebagai implementasi dari pemahaman Q.S Al-Jum'ah (62): 9, meliputi: (a) Siswa melaksanakan shalat Jum'at; (b) Siswa mengetahui ketentuan shalat Jum'at; dan (c) Siswa melakukan praktik shalat Jum'at. (7) Menunaikan shalat jamak dan qasar ketika bepergian jauh (musafir) sebagai implementasi dari pemahaman ketaatan beribadah. (8) Menghargai perilaku semangat menuntut ilmu sebagai implementasi dari pemahaman sifat Allah SWT. (9) Menghargai perilaku ikhlas, sabar, dan pemaaf; (10) Memahami sejarah perjuangan Nabi Muhammad SAW; dan (11) Mengetahui karakter Khalifah dari Khulafaurrasyidin.

Sedangkan konsep operasional variabel Y, yaitu: (1) Mengenali emosi diri sendiri, terdiri dari: (a) Siswa mampu mengetaui kesadaran diri; (b) Siswa mampu mengetahui penilaian diri secara teliti; dan (c) Siswa percaya diri. (2) Mengelola suasana hati, terdiri dari: (a) Siswa mampu mengendalikan diri; (b) Siswa dapat dipercaya; (c) Siswa mampu melakukan kewaspadaan; (d) Siswa mampu adaptabilitas; dan (e) Siswa mampu melakukan inovasi. (3) Memotivasi diri sendiri, terdiri dari: (a) Siswa mampu mendorongan dalam berprestasi; (b) Siswa mampu berkomitmen; (c) Siswa mampu berinisiatif; dan (d) Siswa selalu optimisme. (4) Mengenali emosi orang lain, terdiri dari: (a) Siswa mampu memahami orang lain; (b) Siswa mampu berorientasi pelayanan; (c) Siswa mampu mengembangkan orang lain; (d) Siswa mampu mengatasi keragaman; dan (e) Siswa mampu mengetahui kesadaran politis. (5) Mengembangkan hubungan dengan orang lain, terdiri dari: (a) Pengaruh; (b)Komunikasi; (c) Kepemimpinan; 
(d)Katasilator perubahan; (e) Manajemen konflik; (f) Pengikat jaringan; (g) Kolaborasi dan kooperasi; dan (e) Kemampuan tim.

\section{HASIL}

\section{Gambaran Umum Lokasi Penelitian Profil SMP PGRI Pekanbaru}

SMP PGRI Pekanbaru

beralamatkan di Brigjend Katamso No. 42 Kecamatan Bukit Raya Kelurahan Tangkerang Utara Pekanbaru, Riau. Akreditasi Sekolah ini adalah "A". Sekolah ini berstatus swasta dengan penyelenggara sekolahnya adalah YLPI
PGRI Propinsi Riau. Sekolah yang bernomor statistik 204096007058. Sekolah ini telah dibuka pada tahun 1967. Namun SK / Izin pendirian sekolah dari kanwil Depdikbud baru didapat pada tanggal 31 Desember 1987.

Mengenai akreditasi SMP PGRI Pekanbaru ini diakui tepatnya tanggal 4 Januari 1993, dan sekolah ini dikelompokkan menjadi sekolah yayasan dengan nama yayasan YPLP PGRI DATI RIAU.

Selama berdirinya SMP PGRI Pekanbaru, terjadi beberapa kali pergantian kepala sekolah, yaitu :

Tabel 1

Daftar Nama Kepala Sekolah SMP PGRI Pekanbaru

\begin{tabular}{clc}
\hline NO & \multicolumn{1}{c}{ NAMA KEPALA SEKOLAH } & MASA JABATAN \\
\hline 1 & DR. M. Diah & 1967 \\
\hline 2 & Drs.H.Sugio Hadi Warnoto & 1968 \\
\hline 3 & H.Masri Radmin & $1968-2000$ \\
\hline 4 & H.Bactiar, Bm & $2000-2006$ \\
\hline 5 & Aldian, M.Pd & $2006-$ Sekarang \\
\hline
\end{tabular}

SMP PGRI Pekanbaru memiliki beberapa ruang belajar, perpustakaan, laboratorium, ruang kepala sekolah, ruang rapat, ruang wakil kepala sekolah bidang kurikulum, ruang wakil kepala sekolah bidang HUMAS, ruang wakil kepala sekolah bidang kesiswaan, ruang wakil kepala sekolah bidang sarana dan prasarana, ruang data, ruang $\mathrm{BK}$, ruang UKS, ruang multimedia, majelis guru, ruang TU, koperasi, gudang, dan WC.

\section{Visi dan Misi}

Visi SMP PGRI Pekanbaru adalah: "Menjadikan SMP PGRI Pekanbaru sebagai sekolah berkualitas, berkarakter,berwawasan lingkungan berdasarkan iman dan taqwa, juga menjadikan sekolah SMP PGRI
Pekanbaru bertaraf Internasional di bidag akademis, disiplin, agamis, dan kompetitif di lingkungan sekolah yang bersih, indah, rindang dan alami". Sedangkan misi SMP PGRI Pekanbaru adalah: (1) Meningkatkan mutu serta layanan pendidikan; (2) Mengupayakan pengadaan sarana dan prasarana pembelajaran yang memadai; (3) Menanamkan nilai-nilai pendidikan karakter serta keimanan dan ketakwaan terhadapan Tuhan Yang Maha Esa; (4) Meningkatkan kebersihan, keindahan, ketertiban, serta sekolah hijau; dan (5) Melaksanakan kegiatan ekstrakulikuler guna mengembangkan potensi bakat, minat serta kreatifitas peserta didik.

Tujuan akhir yang diinginkan SMP PGRI Pekanbaru adalah: "Mewujudkan peserta didik yang cerdas, berkualitas, 
beriman, bertaqwa, disiplin, menguasai IPTEK, serta peduli lingkungan.

\section{Hubungan Materi Pembelajaran Pendidikan Agama Islam dengan Kecerdasan Emosional}

Data yang akan disajikan pada penyajian hasil penelitian ini adalah data yang dikumpulkan dari lapangan. Adapun teknik pengumpulan data yang digunakan adalah angket. Hasil angket yang diperoleh diharapkan mampu menunjukkan apakah terdapat hubungan antara pembelajaran Pendidikan Agama Islam dengan kecerdasan emosional siswa kelas VII SMP PGRI Pekanbaru. angket ini diberikan kepada 37 responden yang menjadi sampel dalam penelitian ini, kemudian data hasil angket dimasukkan dalam tabulasi yang merupakan proses mengubah data dan instrument pengumpulan data (angket) menjadi tabel-tabel angka (persentase), dapat dilihat pada tabel-tabel berikut:

Tabel 2

Hasil Angket Materi Pembelajaran PAI (Variabel X)

\begin{tabular}{|c|c|c|c|c|c|c|c|c|c|c|}
\hline \multirow{3}{*}{ No } & \multirow{3}{*}{ Pernyataan } & \multicolumn{8}{|c|}{ Alternatif Jawaban } & \multirow{3}{*}{ Jumlah (\%) } \\
\hline & & \multicolumn{2}{|c|}{ SS } & \multicolumn{2}{|c|}{$\mathbf{S}$} & \multicolumn{2}{|c|}{ JR } & \multicolumn{2}{|c|}{ TP } & \\
\hline & & $\mathbf{F}$ & $\%$ & $\mathbf{F}$ & $\%$ & $\mathbf{F}$ & $\%$ & $\mathbf{F}$ & $\%$ & \\
\hline 1 & $\begin{array}{l}\text { Selain membaca bahasa } \\
\text { arabnya, saya sering } \\
\text { membaca arti dari ayat } \\
\text { alqur'an yang saya baca }\end{array}$ & 3 & 8,11 & 1 & 2,70 & 33 & 89,19 & - & - & $37(100 \%)$ \\
\hline 2 & $\begin{array}{l}\text { Hukum bacaan-bacaan di } \\
\text { dalam alqur'an sangat } \\
\text { penting, saya akan } \\
\text { berusaha menguasainy, } \\
\text { agar bacaan alqur'an } \\
\text { saya benar }\end{array}$ & 9 & 24,32 & 15 & 40,54 & 12 & 32,43 & 1 & 2,70 & $37(100 \%)$ \\
\hline 3 & $\begin{array}{l}\text { Saya melakukan shalat } \\
\text { lima (5) waktu dalam } \\
\text { sehari semalam }\end{array}$ & 27 & 72,97 & 7 & 18,92 & 2 & 5,40 & 1 & 2,70 & $37(100 \%)$ \\
\hline 4 & $\begin{array}{l}\text { Setiap melakukan } \\
\text { perbuatan baik saya } \\
\text { melakukanny karena } \\
\text { Allah }\end{array}$ & 18 & 48,65 & 17 & 45,95 & 2 & 5,40 & - & - & $37(100 \%)$ \\
\hline 5 & $\begin{array}{l}\text { Saya berusaha membaca } \\
\text { alqur'an setiap hari }\end{array}$ & 21 & 56,76 & 7 & 18,92 & 8 & 21,62 & 1 & 2,70 & $37(100 \%)$ \\
\hline 6 & $\begin{array}{l}\text { Saya berusaha } \\
\text { menghindari berbuat dan } \\
\text { berkata buruk agar } \\
\text { malaikat atid tidak } \\
\text { mencatatnya }\end{array}$ & 17 & 45,95 & 11 & 29,73 & 8 & 21,62 & 1 & 2,70 & $37(100 \%)$ \\
\hline 7 & $\begin{array}{l}\text { Saya melakukan wudhu } \\
\text { paling sedikit lima (5) } \\
\text { kali sehari semalam }\end{array}$ & 2 & 5,40 & 25 & 67,57 & 7 & 18,92 & 3 & 8,11 & 37 (100\%) \\
\hline 8 & $\begin{array}{l}\text { Setiap hari saya mandi } \\
\text { paling sedikit dua (2) kali }\end{array}$ & 27 & 72,97 & 9 & 24,32 & 1 & 2,70 & - & - & $37(100 \%)$ \\
\hline 9 & $\begin{array}{l}\text { Saya segera ke masjid } \\
\text { atau mushala saat } \\
\text { mendengar adzan }\end{array}$ & 10 & 27,03 & 26 & 70,27 & 1 & 2,70 & - & - & 37 (100\%) \\
\hline 10 & $\begin{array}{l}\text { Saya tidak pernah } \\
\text { bercanda pada saat } \\
\text { shalat }\end{array}$ & 17 & 45,95 & 7 & 18,92 & 13 & 35,14 & - & - & 37 (100\%) \\
\hline
\end{tabular}




\begin{tabular}{|c|c|c|c|c|c|c|c|c|c|c|}
\hline 11 & $\begin{array}{l}\text { Saya membaca alqur'an } \\
\text { sebelum khotbah dimulai }\end{array}$ & 12 & 32,42 & 15 & 40,54 & 10 & 27,03 & - & - & $37(100 \%)$ \\
\hline 12 & $\begin{array}{l}\text { Saya mandi sebelum } \\
\text { jum'atan }\end{array}$ & 19 & 51,35 & 11 & 29,73 & 7 & 18,92 & - & - & $37(100 \%)$ \\
\hline 13 & $\begin{array}{l}\text { Saya menjamak shalat } \\
\text { sebelum perjalanan jauh }\end{array}$ & 8 & 21,62 & 9 & 24,32 & 11 & 29,73 & 9 & 24,32 & $37(100 \%)$ \\
\hline 14 & $\begin{array}{l}\text { Saya mengqasar shalat } \\
\text { yang ketinggalan karena } \\
\text { perjalanan jauh }\end{array}$ & 11 & 29,73 & 16 & 43,24 & 6 & 16,22 & 4 & 10,81 & $37(100 \%)$ \\
\hline 15 & $\begin{array}{l}\text { Setiap pulang sekolah } \\
\text { saya mengulani pelajaran }\end{array}$ & 18 & 46,65 & 12 & 32,42 & 4 & 10,81 & 3 & 8,11 & $37(100 \%)$ \\
\hline 16 & $\begin{array}{l}\text { Ketika belajar di kelas } \\
\text { saya mendengarkan dan } \\
\text { memperhatikan guru }\end{array}$ & 17 & 45,95 & 15 & 40,54 & 5 & 13,51 & - & - & 37 (100\%) \\
\hline 17 & $\begin{array}{l}\text { Sabar saat mendapat } \\
\text { cobaan atau musibah }\end{array}$ & 14 & 37,84 & 15 & 40,54 & 8 & 21,62 & - & - & $37(100 \%)$ \\
\hline 18 & $\begin{array}{l}\text { Menolong orang tanpaa } \\
\text { ingin disanjung }\end{array}$ & 17 & 45,95 & 10 & 27,03 & 7 & 18,92 & 3 & 8,11 & $37(100 \%)$ \\
\hline 19 & $\begin{array}{l}\text { Saya melakukan amanah } \\
\text { yang diberikan kepada } \\
\text { saya dengan baik }\end{array}$ & 17 & 45,95 & 13 & 35,14 & 7 & 18,92 & - & - & 37 (100\%) \\
\hline 20 & $\begin{array}{l}\text { Setiap berbicara kepada } \\
\text { orang lain saya berkata } \\
\text { jujur }\end{array}$ & 15 & 40,54 & 11 & 29,73 & 6 & 16,22 & 5 & 13,51 & $37(100 \%)$ \\
\hline 21 & $\begin{array}{l}\text { Saya berusaha menjadi } \\
\text { pribadi yang dimiliki oleh } \\
\text { khalifah Abu Bakar As } \\
\text { Sidiq r.a }\end{array}$ & 20 & 54,05 & 9 & 24,32 & 8 & 21,62 & - & - & 37 (100\%) \\
\hline 22 & $\begin{array}{l}\text { Saya berusaha menjadi } \\
\text { pribadi yang dimiliki oleh } \\
\text { khalifah Ali bin Abi } \\
\text { Thalib r.a }\end{array}$ & 18 & 48,65 & 14 & 37,84 & 5 & 13,51 & - & - & 37 (100\%) \\
\hline Total & & 327 & 40,17 & 275 & 33,78 & 171 & 21,01 & 31 & 3,81 & $814(100 \%)$ \\
\hline
\end{tabular}

Sumber: Hasil Olahan Data Lapangan,2015

Berdasarkan tabel di atas dapat disimpulkan bahwa sebagian siswa dapat mengaplikasikan materi pembelajaran pendidikan Agama Islam dalam kehidupan sehari-hari, hanya sebagian siswa yang tidak mengaplikasikan materi pembelajaran pendidikan Agama Islam dalam kehidupaan sehari-harinya. Hal ini menunjukkan bahwa materi pembelajaran pendidikan Agama Islam mampu mempengaruhi di kehidupan siswa.

Tabel 3

Hasil Angket Kecerdasan Emosional (Variabel Y)

\begin{tabular}{|c|c|c|c|c|c|c|c|c|c|c|}
\hline \multirow{3}{*}{ No } & \multirow{3}{*}{ Pernyataan } & \multicolumn{8}{|c|}{ Alternatif Jawaban } & \multirow{3}{*}{$\begin{array}{c}\text { Jumlah } \\
\text { (\%) }\end{array}$} \\
\hline & & \multicolumn{2}{|c|}{ SS } & \multicolumn{2}{|c|}{$\mathbf{S}$} & \multicolumn{2}{|c|}{ JR } & \multicolumn{2}{|c|}{ TP } & \\
\hline & & $\mathbf{F}$ & $\%$ & $\mathbf{F}$ & $\%$ & $\mathbf{F}$ & $\%$ & $\mathbf{F}$ & $\%$ & \\
\hline & $\begin{array}{l}\text { Mengenali emosi diri } \\
\text { sendiri }\end{array}$ & & & & & & & & & \\
\hline 1 & $\begin{array}{l}\text { Saya menyadari keku- } \\
\text { rangan dan kelebihan } \\
\text { yang ada pada diri saya }\end{array}$ & 17 & 45,95 & 15 & 40,54 & 5 & 13,51 & - & - & $37(100 \%)$ \\
\hline 2 & $\begin{array}{l}\text { Setiap mengambil } \\
\text { keputusan dan melaksa- } \\
\text { nakannya, saya berada }\end{array}$ & 12 & 32,43 & 18 & 48,65 & 7 & 18,92 & - & - & $37(100 \%)$ \\
\hline
\end{tabular}




\begin{tabular}{|c|c|c|c|c|c|c|c|c|c|c|}
\hline & dalam kondisi sadar & & & & & & & & & \\
\hline 3 & $\begin{array}{l}\text { Saya meluangkan waktu } \\
\text { untuk merenung dan } \\
\text { belajar dari pengalaman }\end{array}$ & 15 & 40,54 & 12 & 32,43 & 10 & 27,03 & - & - & $37(100 \%)$ \\
\hline 4 & $\begin{array}{l}\text { Saya yakin dengan } \\
\text { kemampuan yang saya } \\
\text { miliki dalam menjalan- } \\
\text { kan tugas yang harus } \\
\text { diselesaikan }\end{array}$ & 13 & 35,14 & 16 & 43,24 & 6 & 16,22 & 2 & 5,41 & $37(100 \%)$ \\
\hline 5 & $\begin{array}{l}\text { Saya mampu membuat } \\
\text { keputusanyang baik } \\
\text { dalam keadaan tertekan }\end{array}$ & 12 & 32,43 & 13 & 35,14 & 7 & 18,92 & 5 & $\begin{array}{c}13,5 \\
1\end{array}$ & $37(100 \%)$ \\
\hline \multicolumn{11}{|c|}{ Mengelola suasana Hati } \\
\hline 6 & $\begin{array}{l}\text { Saya menghadapi } \\
\text { situasi yang sulit } \\
\text { dengan penuh } \\
\text { kesabaran } \\
\end{array}$ & 9 & 24,32 & 11 & 29,73 & 12 & 32,43 & 5 & $\begin{array}{c}13,5 \\
1\end{array}$ & $37(100 \%)$ \\
\hline 7 & $\begin{array}{l}\text { Saya dapat berpikir } \\
\text { jernih dalam keadaan } \\
\text { tertekan }\end{array}$ & 8 & 21,62 & 12 & 32,43 & 14 & 37,84 & 3 & 8,11 & $37(100 \%)$ \\
\hline 8 & $\begin{array}{l}\text { Saya berani mengakui } \\
\text { kesalahan saya sendiri }\end{array}$ & 17 & 45,95 & 12 & 32,43 & 5 & 13,51 & 3 & 8,11 & $37(100 \%)$ \\
\hline 9 & $\begin{array}{l}\text { Dalam menjalankan } \\
\text { tugas, saya memegang } \\
\text { teguh prinsip kejujuran }\end{array}$ & 12 & 32,43 & 13 & 35,14 & 10 & 27,03 & 2 & 5,41 & $37(100 \%)$ \\
\hline 10 & $\begin{array}{l}\text { Saya memenuhi janji } \\
\text { yang telah saya buat } \\
\text { dengan siapapun }\end{array}$ & 15 & 40,54 & 12 & 32,43 & 8 & 21,62 & 2 & 5,41 & $37(100 \%)$ \\
\hline \multicolumn{11}{|c|}{ Memotivasi diri sendiri } \\
\hline 11 & $\begin{array}{l}\text { Saya berjuang untuk } \\
\text { meraih hasil yang } \\
\text { memuaskan sesuai } \\
\text { dengan tujuan yang } \\
\text { saya inginkan }\end{array}$ & 12 & 32,43 & 18 & 48,65 & 7 & 18,92 & - & - & $37(100 \%)$ \\
\hline 12 & $\begin{array}{l}\text { Saya terus belajar untuk } \\
\text { terus meningkatkan } \\
\text { hasil kerja saya }\end{array}$ & 14 & 37,84 & 18 & 48,65 & 5 & 13,51 & - & - & $37(100 \%)$ \\
\hline 13 & $\begin{array}{l}\text { Untuk mengambil } \\
\text { keputusan dalam } \\
\text { organisasi, saya } \\
\text { menggunakan nilai-nilai } \\
\text { kelompok }\end{array}$ & 17 & 45,95 & 15 & 40,54 & 5 & 13,51 & - & - & $37(100 \%)$ \\
\hline 14 & $\begin{array}{l}\text { Saya aktif mencari } \\
\text { peluang untuk } \\
\text { memenuhi misi } \\
\text { kelompok }\end{array}$ & 10 & 27,03 & 17 & 45,95 & 9 & 24,32 & 1 & 2,70 & $37(100 \%)$ \\
\hline \multicolumn{11}{|c|}{ Mengenali emosi orang lain } \\
\hline 15 & $\begin{array}{l}\text { Saya turut merasakan } \\
\text { apa yang dirasakan oleh } \\
\text { orang lain }\end{array}$ & 12 & 32,43 & 13 & 35,14 & 9 & 24,32 & 3 & 8,11 & $37(100 \%)$ \\
\hline 16 & $\begin{array}{l}\text { Saya menghargai } \\
\text { kemajuan dan } \\
\text { keberhasilan yang } \\
\text { diraih orang lain }\end{array}$ & 15 & 40,54 & 10 & 27,03 & 8 & 21,62 & 4 & $\begin{array}{c}10,8 \\
1\end{array}$ & $37(100 \%)$ \\
\hline 17 & $\begin{array}{l}\text { Ketika ada teman yang } \\
\text { menceritakan } \\
\text { masalahnya kepada } \\
\text { saya, saya akan }\end{array}$ & 13 & 35,14 & 15 & 50,54 & 9 & 24,32 & - & - & $37(100 \%)$ \\
\hline
\end{tabular}




\begin{tabular}{|c|c|c|c|c|c|c|c|c|c|c|}
\hline & $\begin{array}{l}\text { mendengarkannya } \\
\text { dengan baik }\end{array}$ & & & & & & & & & \\
\hline 18 & $\begin{array}{l}\text { Saya menawarkan } \\
\text { bantuan yang sesuai } \\
\text { kepada orang lain } \\
\text { dengan senang hati }\end{array}$ & 15 & 40,54 & 13 & 35,14 & 6 & 16,22 & 3 & 8,11 & $37(100 \%)$ \\
\hline \multicolumn{11}{|c|}{$\begin{array}{l}\text { Mengembangkan hubungan } \\
\text { dengan orang lain }\end{array}$} \\
\hline 19 & $\begin{array}{l}\text { Saya menyesuaikan } \\
\text { materi pembicaraan } \\
\text { dengan para pendengar }\end{array}$ & 15 & 40,54 & 13 & 35,14 & 9 & 24,32 & - & - & $37(100 \%)$ \\
\hline 20 & $\begin{array}{l}\text { saya membangung } \\
\text { kebersamaan dan } \\
\text { komitmen dalam } \\
\text { bekerja }\end{array}$ & 14 & 37,84 & 10 & 27,03 & 7 & 18,92 & 6 & $\begin{array}{c}16,2 \\
2\end{array}$ & $37(100 \%)$ \\
\hline 21 & $\begin{array}{l}\text { Saya membangkitkan } \\
\text { semangat anggota untuk } \\
\text { meraih kesuksesan } \\
\text { bersama }\end{array}$ & 11 & 29,73 & 12 & 32,43 & 9 & 24,32 & 5 & $\begin{array}{c}13,5 \\
1\end{array}$ & $37(100 \%)$ \\
\hline 22 & $\begin{array}{l}\text { Saya memberikan } \\
\text { teladan dalam bekerja } \\
\text { kepada para anggota }\end{array}$ & 16 & 43,24 & 11 & 29,73 & 6 & 16,22 & 4 & $\begin{array}{c}10,8 \\
1\end{array}$ & $37(100 \%)$ \\
\hline \multicolumn{2}{|c|}{ Total } & 294 & 36,12 & 299 & 36,73 & 173 & 25,25 & 48 & 5,90 & $\begin{array}{c}814 \\
(100 \%)\end{array}$ \\
\hline
\end{tabular}

Sumber: Hasil Olahan Data Lapangan, 2015.

Berdasarkan tabel di atas dapat disimpulkan bahwa sebagian besar siswa telah melaksanakan kecakapankecakapan kecerdasan emosional dan hanya sebagian kecil saja dari siswa yang tidak melaksanakannya.

\section{Analisis Inferensial}

Analisis Inferensial ini digunakan untuk mengetahui hubungan materi pembelajaran pendidikan agama islamdengan kecerdasan emosional siswa, dalam hal ini penulis menggunakan rumus korelasi product moment. Maka $r_{\text {hitung }}$ menggunakan rumus korelasi product moment adalah:

$$
\begin{aligned}
& r_{x y}=\frac{n\left(\sum X Y\right)-\left(\sum X\right) \cdot\left(\sum Y\right)}{\sqrt{\left\{n \cdot \sum X^{2}-\left(\sum X\right)^{2}\right\} \cdot\left\{n \cdot \sum Y^{2}-\left(\sum Y\right)^{2}\right\}}} \\
& =\frac{37(154082)-(2386) \cdot(2360)}{\sqrt{\left\{37 \cdot 155872-(2386)^{2}\right\} \cdot\left\{37 \cdot 153528-(2360)^{2}\right\}}} \\
& =\frac{70074}{90768,909} \\
& =0,77
\end{aligned}
$$

Dari hasil yang didapat menunjukkan bahwa terdapat hubungan yang kuat antara variabel (X) Materi Pembelajaran Pendidikan Agama Islam dengan variabel (Y) Kecerdasan Emosional Siswa.

Sedangkan nilai $t$ pada korelasi product moment menggunakan uji $t$, yaitu:

$$
\begin{gathered}
t_{\text {hitung }}=\frac{r \sqrt{n-2}}{\sqrt{1-r^{2}}} \\
=\frac{0,77 \sqrt{37-2}}{\sqrt{1-(0,77)^{2}}} \\
=7,125
\end{gathered}
$$

Dalam membandingkan nilai $t_{\text {hitung }}$ dengan $t_{\text {tabel }}$, maka derajat bebas $(\mathrm{db})$ harus ditentukan. Penentuan derajat bebas $(\mathrm{db})$ dengan rumus:

$d f=N-n r$

$$
=37-2
$$

$=35$

Maka untuk menentukan apakah Ha diterima atau ditolak dan sebaliknya 
dengan kriteria $t_{\text {hitung }}>t_{\text {tabel }}$, dengan $\alpha$ $=0,05$ maka diperoleh $t_{\text {tabel }}=1,689$, nilai ini jelas jauh lebih kecil dari $t_{\text {hitung }}$ yang diperoleh yaitu 7,125

Setelah $t_{\text {hitung }}$ diperoleh yaitu 7,125 selanjutnya pengujian hipotesis dengan membandingkan $t_{\text {hitung }}$ dengan $t_{\text {tabel }}$. Karena $t_{\text {hitung }} 7,125>t_{\text {tabel }} 1,689$, maka Ha diterima dan Ho ditolak, artinya terdapat hubungan yang signifikan materi pembelajaran pendidikan agama islam dengan kecerdasan emosional siswa kelas VII SMP PGRI Pekanbaru.

Koefisien determinasi digunakan untuk menentukan seberapa besar materi pembelajaran pendidikan Agama Islam mempengaruhi kecerdasan emosional siswa kelas VII SMP PGRI Pekanbaru. Untuk menghitung koefisien determinasi digunakan rumus sebagai berikut:

$K D=r^{2} \times 100 \%$

$=0,5929 \times 100 \%$

$=59,29 \%$

$=59 \%$

Hal ini menunjukkan bahwa kecerdasan emosional dihubungkan oleh materi pembelajaran pendidikan agama islam sebesar 59\% sedangkan $41 \%$ dihubungkan oleh faktor lain.

\section{PEMBAHASAN}

Dari hasil analisis data terdapat nilai $t_{\text {hitung }}$ sebesar 7,125 sedangkan $t_{\text {tabel }}$ diperoleh nilai sebesar 1,689. Hal ini berarti bahwa $t_{\text {hitung }} 7,125>t_{\text {tabel }} 1,689$ artinya terdapat hubungan yang signifikan antara materi pembelajaran pendidikan Agama Islam dengan kecerdasan emosional siswa kelas VII SMP PGRI Pekanbaru.Hal ini sejalan dengan uji hipotesis yang menyatakan bahwa $_{\text {hitung }} 7,125>t_{\text {tabel }} 1,689$, maka Ha diterima dan Ho ditolak, artinya terdapat hubungan yang signifikan antara materi pembelajaran pendidikan Agama Islam dengan kecerdasan emosional siswa kelas VII SMP PGRI Pekanbaru. Berdasarkan korelasi product moment diperoleh nilai $t_{\text {hitung }}=$ 7,125 dan berdasarkan derajat bebas (db) diperoleh nilai $t_{\text {tabel }}=1,689$, artinya $t_{\text {hitung }}>t_{\text {tabel }}$.

Maka Ha diterima dan Ho ditolak.

Data-data yang telah diperoleh juga menunjukkan bahwa kecerdasan emosional berhubungan dengan pembelajaran materi pendidikan Agama Islam sebesar 59\%, sedangkan sisanya $41 \%$ berhubungan oleh hal-hal lain. Hal ini menunjukkan bahwa terdapat hubungan yang kuat antara variabel (X) Materi Pembelajaran Pendidikan Agama Islam dengan variabel (Y) kecerdasan emosional.

\section{SIMPULAN}

Berdasarkan hasil olahan dan analisis data yang telah penulis lakukan, maka dapat disimpulkan bahwa terdapat hubungan yang signifikan antara pembelajaran materi pendidikan Agama Islam terhadap kecerdasan emosional siswa kelas VII SMP PGRI Pekanbaru. Kesimpulan ini di peroleh berdasarkan rumus $\alpha=0,05$ maka diperoleh dari $t_{\text {hitung }}$ yang diperoleh yaitu 7,125 dan diperoleh $t_{\text {tabel }}=1,689$. Jadi, $t_{\text {hitung }}>t_{\text {tabel }}$, artinya Ha diterima dan Ho ditolak.

Data-data yang telah diperoleh juga menunjukkan bahwa kecerdasan emosional berhubungan dengan pembelajaran materi pendidikan Agama Islam sebesar 59\%, sedangkan sisanya $41 \%$ berhubungan oleh hal-hal lain. Hal ini menunjukkan bahwa terdapat hubungan yang kuat antara variabel (X) Materi Pembelajaran Pendidikan Agama Islam dengan variabel $(\mathrm{Y})$ kecerdasan emosional.

Setelah mengetahui hasil penelitian yang penulis lakukan, ada 
beberapa saran yang ingin penulis sampaikan, antara lain: (1) Bagi siswa,untuk lebih meningkatkan dan memperhatikan kecakapan-kecakapan kecerdasan emosional agar dalam menjalani hidup tidak berorientasi dengan keinginan, tetapi kebutuhan; dan (2) Bagi guru, khususnya guru pendidikan Agama Islam untuk lebih meningkatkan pembelajaran pendidikan Agama Islam dengan memperhatikan setiap tahapan-tahapan dalam proses pembelajaran agar dapat meningkatkan kecerdasan emosional siswa. Bagi guru lain sebaiknya memperhatikan kecakapan-kecakapan emosional dalam kegiatan pembelajaran karena menerapkan contoh-contoh kecakapan kecerdasan emosional kepada siswa tidak hanya tugas guru pendidikan Agama Islam tetapi juga guru bidang studi lain, misalnya memulai pembelajaran diawali bengan bismillaah dan diakhiri alhamdallah. Pembiasaan ini dapat memberikan nilai-nilai religius pada siswa yang akan mengarahkan mereka pada kecerdasan emosional.

\section{DAFTAR RUJUKAN}

Agustian, Ary Ginanjar. 2005. Rahasia Sukses Membangun Kecerdasan Emosi dan Spiritual ESQ Emotional Spiritual Quotient The ESQ Way 165, lihsan 6 Rukun Iman dan 5 Rukun Islam. Jakarta: Arga Wijaya Persada.

Arikunto, Suharsimi. 2010. Prosedur Penelitian Suatu Pendekatan Praktek. Jakarta: Rineka Cipta.

Choeroni, et al., 2013. Pendidikan Agama Islam. Semarang: Erlangga.

Dairi, Rizal. 2010. Metodologi Penelitian Berbasis Kompetensi. Pekanbaru: UIR Pers.
Daradjat, Zakiah. 1996. Ilmu Pendidikan Islam. Jakarta: Bumi Aksara.

Goleman, Daniel. 2000. Emotional Intelligent, Kecerdasan Emosional EI Lebih Penting daripada IQ. Terj. Hermaya. Jakarta: Gramedia Pustaka.

Marimba, Ahmad D., 1989. Pengantar Filsafat Pendidikan Islam. Bandung: Al-Ma'arif.

Ramayulis. 2006. Ilmu Pendidikan Islam. Jakarta: Kalam Mulia.

Riduan dan Akdon. 2010. Pengantar statistika Untuk Penelitian Pendidikan Sosial, Ekonomi, dan Bisinis. Bandung: Alfabeta.

Ridwan dan Sunarto. 2007. Pengantar Statistik untuk Penelitian. Bandung: Alfabeta.

Ridwan. 2010. Belajar Mudah Penelitian. Bandung: Alfabeta.

Sudijono, Anas. 2007. Pengantar statistik pendidikan. Jakarta: Raja grafindo Persada.

Evaluasi Pendidikan.
Rajawali Press.
Sukarta:
Suhartono, Suparlan. 2008. Wawasan
Pendidikan: Sebuah Pengantar
Pendidikan. Yogyakarta: Ar-
Ruzzmedia.
Team Pustaka Phoenix. 2008. Kamus Besar Bahasa Indonesia Edisi Baru. Jakarta Barat: Media Pustaka Phoenix.

Uhbiyati, Nur. 1998. Ilmu Pendidikan Islam. Bandung: Pustaka Setia.

Uno, Hamzah B., 2010. Orientasi Baru dalam Psikologi Pembelajaran. Jakarta: Bumi Aksara.

Yudhawati, Ratna dan Haryanto, Dany. 2011. Teori-Teori Dasar Psikologi Pendidikan. Jakarta: Prestasi Pustaka. 